\title{
Importance of Biodiagnostics and Irrigation Gray-Brown Soils
}

\author{
Hasanova Turkan Allahverdi ${ }^{1, *}$, Mammadova Gunay Israphil ${ }^{1,2}$, Bunyatova Lala Novruz ${ }^{2}$, \\ Gahramanova Aida Yarish ${ }^{2}$ \\ ${ }^{1}$ Institute of Soil Science and Agro Chemistry, National Academy of Sciences of Azerbaijan, Azerbaijan
${ }^{2}$ Faculty of Chemistry and Biology, Department of Biology and Its Teaching Methods, Sumgait State University, Azerbaijan
}

Received March 8, 2021; Revised May 15, 2021; Accepted June 6, 2021

\section{Cite This Paper in the following Citation Styles}

(a): [1] Hasanova Turkan Allahverdi, Mammadova Gunay Israphil, Bunyatova Lala Novruz, Gahramanova Aida Yarish, "Importance of Biodiagnostics and Irrigation Gray-Brown Soils," Universal Journal of Agricultural Research, Vol. 9, No. 3, pp. 63 - 69, 2021. DOI: 10.13189/ujar.2021.090301.

(b): Hasanova Turkan Allahverdi, Mammadova Gunay Israphil, Bunyatova Lala Novruz, Gahramanova Aida Yarish (2021). Importance of Biodiagnostics and Irrigation Gray-Brown Soils. Universal Journal of Agricultural Research, 9(3), 63 - 69. DOI: 10.13189/ujar.2021.090301.

Copyright $\bigcirc 2021$ by authors, all rights reserved. Authors agree that this article remains permanently open access under the terms of the Creative Commons Attribution License 4.0 International License

\begin{abstract}
A comparative study of the biological parameters of gray-brown soils in natural cenoses and agrocenoses is an actual problem and has great practical importance. The article shows the results of modern scientific research in the field of biodiagnostics of graybrown soils. These studies make it possible to use biological indicators not only in morphological description, but also systematics and biological diagnostics of gray-brown soils. For the first time in the study area, a comparative study of the number of phytocomplexes was carried out and the importance of studying other diagnostic biological indicators was determined. Biological studies of gray-brown soils can be used as biodiagnostic tests in the systematization and classification of gray-brown soils formed in arid ecosystems. Biological diagnostics are important for conducting biological tests and determining the suitability of the soil for agriculture [10]. Along with the study of biological parameters in moist soils of natural cenoses and irrigated soils of agrocenoses, the total moisture content of these soils was studied in different seasons. The qualitative composition of irrigation water in different seasons has been studied for 3 years and the positive impact on irrigated lands was determined. The article presents some results of studies carried out on the Goychay River and its floodplains over 3 years. In accordance with the hydrographic regime and relief of the
\end{abstract}

Goychay River, the qualitative composition of the water flowing in different parts of the river, dependent particles, impurities, and the degree of clay content were studied. The article shows the bio-diagnostic properties of the soil, the qualitative and microbiological composition of irrigation water in agrocenoses, as well as in natural cenoses of the study area. It was found that irrigation water has a positive effect on soils and plants of agrocenoses.

Keywords Natural Cenosis, Agrocenosis, Biological Indicators, Irrigation Water, Amount of Salts, Water Ecosystems

\section{Introduction}

Soil contains a very high, but mostly unknown biodiversity and biology, remains an under studied topic. The soil formation, the further complicated process develops under an influence of economical factor complex. A base of this process is a great geological and little biological cycle of the matter $[2,3,5]$.

One of the most important tasks facing the soil scientists of Azerbaijan is to study the impact of irrigation water on the soil [1]. 
The study of biological indicators is of great importance for the involvement of gray-brown soils in agriculture, paying special attention to the conservation and effective use of these soils. From this point of view, comparative studies in natural biocenoses and agrocenoses, a comparative study of biological indicators and physicochemical properties of soil, dedicated to the topic of current and modern biodiagnostics, also has scientific and practical importance.

At present, as a result of intensive agricultural use of the republic's lands, ineffective reclamation measures, rapid deforestation and intensive, ineffective, unsystematic use of pastures, various erosion processes have intensified, leading to the degradation of soil vegetation. It is very important to solve such important issues as the protection of soils in the study areas, the restoration and increase of their fertility, the achievement of high productivity of agricultural crops, the protection of biological diversity $[7,8,9]$.

For the first time in the territories studied by us, the authors carried out comprehensive and comparative studies of the properties of natural cenoses and agrocenoses on gray-brown soils. The phytostructure, dynamics of phytomass, the relationship of phytochemicals with soil humus, groups and types of soil invertebrates, the number and group composition of microorganisms, and enzymatic activity were also studied. The groundwater level is deep ( 2 meters). Optimal temperatures (suitable for biological processes) from 10.213.9-21.3 ${ }^{\circ} \mathrm{C}$ to $15.1-23.6{ }^{\circ} \mathrm{C}$ are recorded in March, April, May and October.

Compared to other regions of Azerbaijan, the biological diagnostic indicators of the dominant lands of the Agsu and Goychay region have been poorly studied. We studied the main biological diagnostic indicators in the dynamics of different seasons for 3 years. Biological diagnostics are important for conducting biological tests and determining the suitability of the soil for agriculture $[4,6]$.

Compared to other regions of Azerbaijan,the biological diagnostic indicators of the dominant lands of the Goychay regions are poorly studied. We have selected these regions as research areas and studied the main biological diagnostic indicators in the dynamics of different seasons over 3 years. Biological diagnostics are important for conducting biological tests and determining the suitability of the soil for agriculture.

\section{Object of Research and Methods}

Taking into account the geomorphological structure, relief, sediments, soil and vegetation, the level of groundwater, the seasonal nature of river floods, the key study areas were selected. Parcel coordinate systems are determined using GPS. 40 $37^{\prime} 40.8^{\prime \prime N} \quad 47^{\circ} 45^{\prime} 00.7^{\prime \prime} \mathrm{E}$; $40^{\circ} 36^{\prime} 21.6^{\prime \prime} \mathrm{N} 47^{\circ} 44^{\prime} 53.9^{\prime \prime} \mathrm{E} ; 40^{\circ} 36^{\prime} 57.7^{\prime \prime} \mathrm{N} 47^{\circ} 45^{\prime} 04.4^{\prime \prime} \mathrm{E}$ $40^{\circ} 37^{\prime} 47.9^{\prime \prime} \mathrm{N} 47^{\circ} 45^{\prime} 14.6^{\prime \prime} \mathrm{E} ; 40^{\circ} 37^{\prime} 08.9^{\prime \prime} \mathrm{N} 47^{\circ} 43^{\prime} 37.9^{\prime \prime} \mathrm{E}$; $40^{\circ} 37^{\prime} 02.8^{\prime \prime} \mathrm{N} 47^{\circ} 44^{\prime} 30.4^{\prime \prime} \mathrm{E}$ and etc. River water samples were collected by bathometry, and Susla Agar was selected to isolate fungal strains. The samples were planted and incubated in the dark at $28^{\circ} \mathrm{C}$. After 3-8 days after incubation, it was observed under a microscope and transferred to Petri dishes. When carrying out physicochemical and biological analyzes, the generally accepted methods of soil science and soil biology were used. Researches of soil crops and water samples were conducted in seasons for three years.

\section{Results}

The Goychay River has a well-developed river network. Results of the study showed that the irrigation water of the Goychay River transports a significant amount of watersoluble humus, nutrients and other products to the fields, which also significantly affects the fertility, nutrient content and diagnostic characteristics of irrigated lands. Along with organic and nutrient substances, large quantities of salt and salt ions are delivered to the fields with irrigation water. The amount of salt and salt ions applied by water per hectare varied depending on the years of research. The determination of quantitative and qualitative indicators of water resources allows you to effectively manage and use them. Therefore, the study of the current state of water resources should be a priority. Large quantities of suspended particles are supplied to the study area by irrigation water. Dependent river tributaries provide a sufficient amount of humus (2.18-1.99\%) and nitrogen $(0.10-0.19 \%)$, a slightly alkaline medium $(\mathrm{pH}=$ 7.3-7.6). Low mineralization of groundwater is characteristic $(0.95-1.20 \mathrm{~g} / \mathrm{l})$. The general chemical composition of the alluvial deposits forming the soil is $\mathrm{SiO}_{2}(58.9-65.7 \%)$, the composition is dominated by $\mathrm{R}_{2} \mathrm{O}_{3}$ $\left(\mathrm{Al}_{2} \mathrm{O}_{3}=21.0-25.7 \% ; \mathrm{Fe}_{2} \mathrm{O}_{3}=8.5-10.9 \%\right)$.

The composition of ions in this water source varied depending on the rivers (picture 1,2). The content of hydrocarbon ions was higher than that of other ions $(0.200$ $\mathrm{g} / \mathrm{L}$ ). The second place among the anions was taken by the sulfate ion. Here its value fluctuated within $0.066 \mathrm{~g} / \mathrm{l}$. The amount of chloride ion in the waters was $0.039 \mathrm{~g} / 1$. The salt content forms a visible sequence: $\mathrm{HCO}_{3}>\mathrm{SO}_{4}{ }^{-2}>\mathrm{Cl}^{-}$. The number of cationic elements in the salt content of the studied tea is slightly different. The quantity of calcium ions in these waters is higher than that of magnesium. $\left(\mathrm{Ca}^{+2}>\mathrm{Mg}^{+2}\right)$. The $\mathrm{Na}_{1}+\mathrm{K}_{1}$ index was $0.019 \mathrm{~g} / \mathrm{l}$. (table 1).

Table 1. Salt and ion content of Goychay river waters $(\mathrm{g} / \mathrm{l})$

\begin{tabular}{|c|c|c|c|c|c|c|c|c|c|}
\hline Dry residue & Amount of salt & $\mathrm{SO}_{4}{ }^{-2}$ & $\mathrm{HCO}_{3}^{-}$ & $\mathrm{Cl}^{-}$ & $\mathrm{Na}^{1}+\mathbf{K}^{1}$ & $\mathrm{Ca}^{+2}$ & $\mathrm{Mg}^{+2}$ & $\mathbf{P}_{2} \mathbf{O}_{5}$ & $\mathbf{N H}_{3}$ \\
\hline 0.490 & 0.408 & 0.072 & 0.200 & 0.039 & 0.019 & 0.058 & 0.036 & 0.52 & 0.401 \\
\hline
\end{tabular}


In terms of chemical composition, the water of the Goychay River is predominantly hydro carbonate. The salinity rate is $400 \mathrm{mg} / \mathrm{l}$. The rate of mineralization in the upper reaches of the river ranges from $170-380 \mathrm{mg} / 1$, and in the lower reaches - 295-490 mg/l. The second place among the anions was taken by $\mathrm{SO}^{-2}$. Here, its value fluctuated within $0.072 \mathrm{~g} / \mathrm{l}$. The amount of $\mathrm{Cl}^{-}$was in water samples $(0.039 \mathrm{~g} / \mathrm{l})$. The salt content in the studied river forms a visible sequence: $\mathrm{HCO}_{3}>\mathrm{SO}_{4}{ }^{-2}>\mathrm{Cl}^{-}$. The number of cationic elements in the salinity of river water for irrigation is somewhat different. The quantity of calcium ions in these waters is higher than that of magnesium. $\left(\mathrm{Ca}^{+2}>\mathrm{Mg}^{+2}\right)$. The $\mathrm{Na}_{1}+\mathrm{K}_{1}$ index was 0.019 $\mathrm{g} / \mathrm{l}$. The results of the analysis of seasonal studies of the content of nutrients in dependent particles of irrigation water show that a significant quantity of nutrients is introduced to the fields by dependent water particles. This has a positive effect on the fertility of irrigated lands and an increase in their productivity.

River water is used in the region as drinking water, in agriculture,for the irrigation of crops. The main regime of river water supply is precipitation, groundwater, lakes and other small rivers. (figure 1,2)

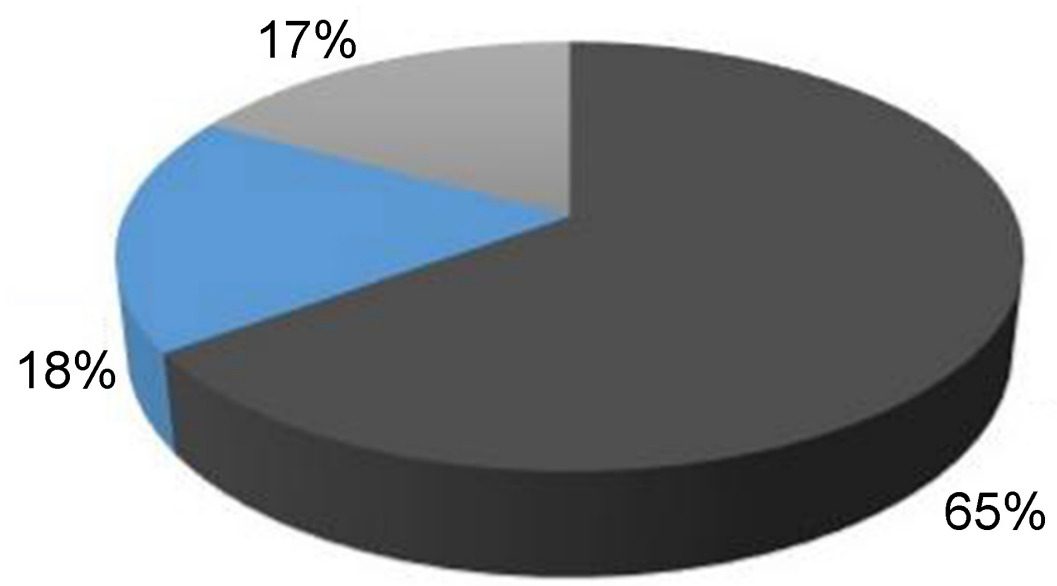

alaciers = groundwater a river and lakes

Figure 1. Goychay river water use scheme

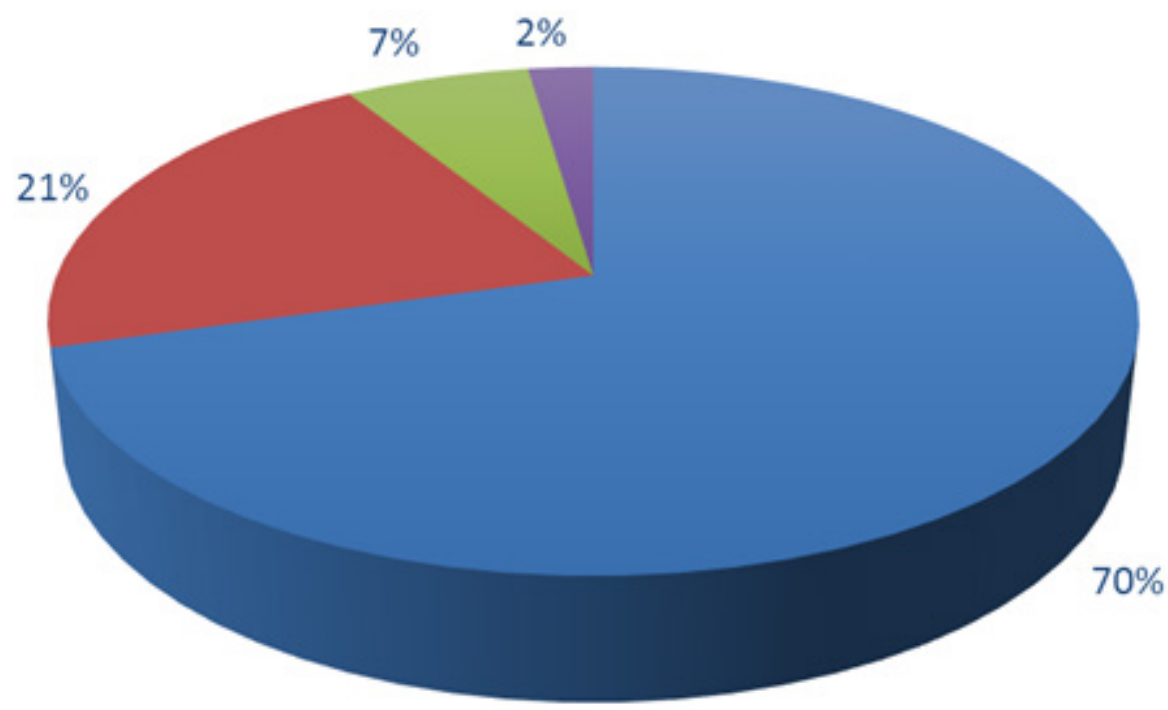

aglaciers agroundwater a river and lakes atmospheric moisture

Figure 2. Water content of Goychay river valley 


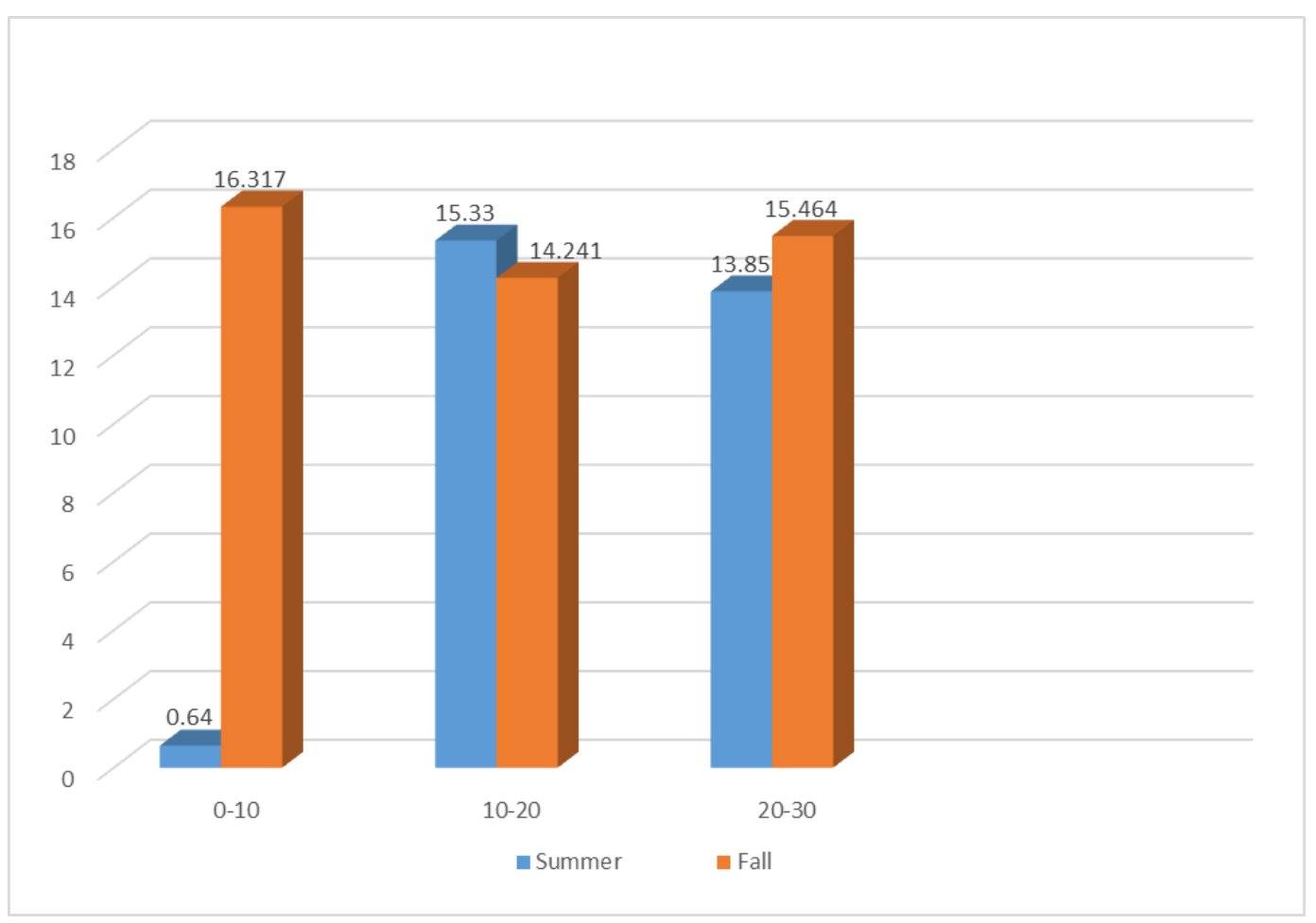

Figure 3. Humidity changes at different depths of the soil in spring and autumn

A comparative study of changes in anthropogenic impacts on irrigated soils. The following results were obtained as follows. Activities such as irrigation, cultivation, fertilization created the basis for the growth of the humus layer of soils. In agrocenoses, during the treatment of soil reclamation processes, during irrigation with river water, the lower layers of the soil mix with the upper fertile layers, and with the distribution of humus along the profile, the amount of total moisture in different layers is relatively large. The results of three consecutive studies of total soil moisture in different years are considered an important indicator of the involvement of wet soils in agriculture. In summer, the total soil moisture decreases. With the autumn coming the amount of precipitation increases.

Soils studied by us, changes in the total and hygroscopic moisture content of genetic residues persisted mainly in the spring and autumn. (fig.3)

As can be seen from the figure, the total moisture content of wet soils decreases in the summer. In the fall season, the amount of precipitation increases, the groundwater level rises, and the total soil moisture at a depth of $0-10 \mathrm{~cm}$ was a maximum of $0.84 \%$ in summer and $16.31 \%$ in autumn. At a depth of $10-20 \mathrm{~cm}$, the values were $15.33 \%$ and $14.23 \%$. At a depth of $20-30 \mathrm{~cm}$ in summer, it was $13.85 \%$, in autumn - a maximum of $15.48 \%$. The comparison of natural cenoses and agrocenoses shows that the moisture content of soils under alfalfa and cereals was higher than in soils under plants used in natural cenoses. Comparison of seasonal fluctuations shows that in autumn the humidity was higher in all cenoses than in summer. In addition to easily soluble salt, the anions contain gypsum in the middle horizons, the amount of which ranges from $0.62-2.08 \mathrm{mg} / \mathrm{eg}$ for cenoses to $0.83-1.25 \mathrm{mg} / \mathrm{eg}$. The highest values of humus and nitrogen in cultural cenoses (clover) are $3.48 \%$ and $0.29 \%$ in the layer $0-29 \mathrm{~cm}, 29-57$ which reaches 2.19 $1.24 \%$ and $0.23-0.17 \%$ in soil layers $57-102 \mathrm{~cm}$. Only in layers $102-150 \mathrm{~cm}$ and $150-170 \mathrm{~cm}$ does their number decrease to $1.07-0.17 \%$ and $0.05-0.05 \%$. A comparative diagram of soil moisture in the spring, summer and autumn of cereal and biennial clover of cultural cenoses, as well as moist soils of natural cenoses. Thus, it was found that the lowest moisture content is observed in natural cenoses, and in the soils of cultural cenoses, under the influence of irrigation water, moisture retention in the soil increases; and in agrocenoses there are optimal conditions for soil biota. In natural cenoses at a depth of $0-10 \mathrm{~cm}$, the moisture content in the soil layer was $9.84 \%$, in the soil layer $20-30 \mathrm{~cm}-13.85 \%$. Moisture in the $0-10$ $\mathrm{cm}$ soil layer in the cereal agrocenosis was $15.07 \%$, in 20 $30 \mathrm{~cm}-19.58 \%$, in the clover agrocenosis (two-year clover) - 19.55 and $15.13 \%$, respectively. The role of physicochemical processes in the metabolism of natural soil is very important. These processes manifest themselves in elemental absorption by the soil. Physicochemical processes also have a great impact on the biological properties of the soil. As indicated in the table, a moisture content of $16.3 \%$ was determined in the soil layer of $0-10 \mathrm{~cm}$ and a moisture content of $15.48 \%$ at a depth of $20-30 \mathrm{~cm}$ in untreated soils. Moisture was $19.16 \%$ in the upper layer of $0-10 \mathrm{~cm}$ and $48.72 \%$ in $20-30 \mathrm{~cm}$ in 
the grain field, $21.7 \%$ in the upper layer and $21.5 \%$ in the lower layer in the irrigated clover agrocenosis.

It was found from a comporative study of soil moisture in soils of natural and irrigated cenoses that irrigation with river water has a positive effect on the quantity and quality of soil. (fig.4)

In addition to readily soluble salt anions contain gypsum in the middle horizons, the amount of which ranges from $0.62-2.08 \mathrm{mg} / \mathrm{eg}$. for cenoses to $0.83-1.25$ $\mathrm{mg} / \mathrm{eq}$. the highest values of humus and total nitrogen in agrocenoses are $3.48 \%$ and $0.29 \%$ in the layer $0-29 \mathrm{~cm}$, $29-57$ reaching $2.19-1.24 \%$ and $0.23-0.17 \%$ in soil layers $57-102 \mathrm{~cm}$. Only in layers $102-150 \mathrm{~cm}$ and $150-170 \mathrm{~cm}$ does their number decrease to $1.07-0.17 \%$ and $0.05-0.05 \%$.

Phytotest is an important part of biodiagnostics, since the plant world and its productivity are a key factor in soil formation. Plant biomass is an important factor that provides the soil with organic matter and participates in the process of humus formation. There is a natural relationship between soil type and natural vegetation. The height of the bushes is from $80 \mathrm{~cm}$ to $150 \mathrm{~cm}$, and the distance between them is from $1.5 \mathrm{~m}$ to $7 \mathrm{~m}$.

Gray-brown soils are rich in spore bacteria and actinomycetes. The number of microorganisms in a natural cenosis depends on hydrothermal conditions, anthropogenic impact on the agrocenosis subject to anthropogenic activity. This activity is associated with the transfer of relatively stable forms of organic matter and the transformation of products synthesized by microorganisms. Since sporulating bacteria have a powerful enzymatic apparatus, they use substances that cannot be assimilated by non-spore-forming bacteria, and enrich the environment with proteins through microbial synthesis. Favorable conditions for the development of microorganisms appear in spring and autumn, and the activity of microbiological processes decreases with the weakening of hydrothermal conditions in summer. The dynamics of the number of microorganisms in the natural cenosis also varies depending on hydrothermal conditions and anthropogenic impact on the agrocenosis subject to anthropogenic activity. The number of microorganisms in the soil depends on the level of plant nutrition, the intensity of metabolism, and the phase of plant development.

Registered in the study of microscopic fungi belong to Aspergillus, Alternaria, Fusarium, Rhisopus, Trichoderma, Penicillum, Mucor, Mycelia sterilia by genus.

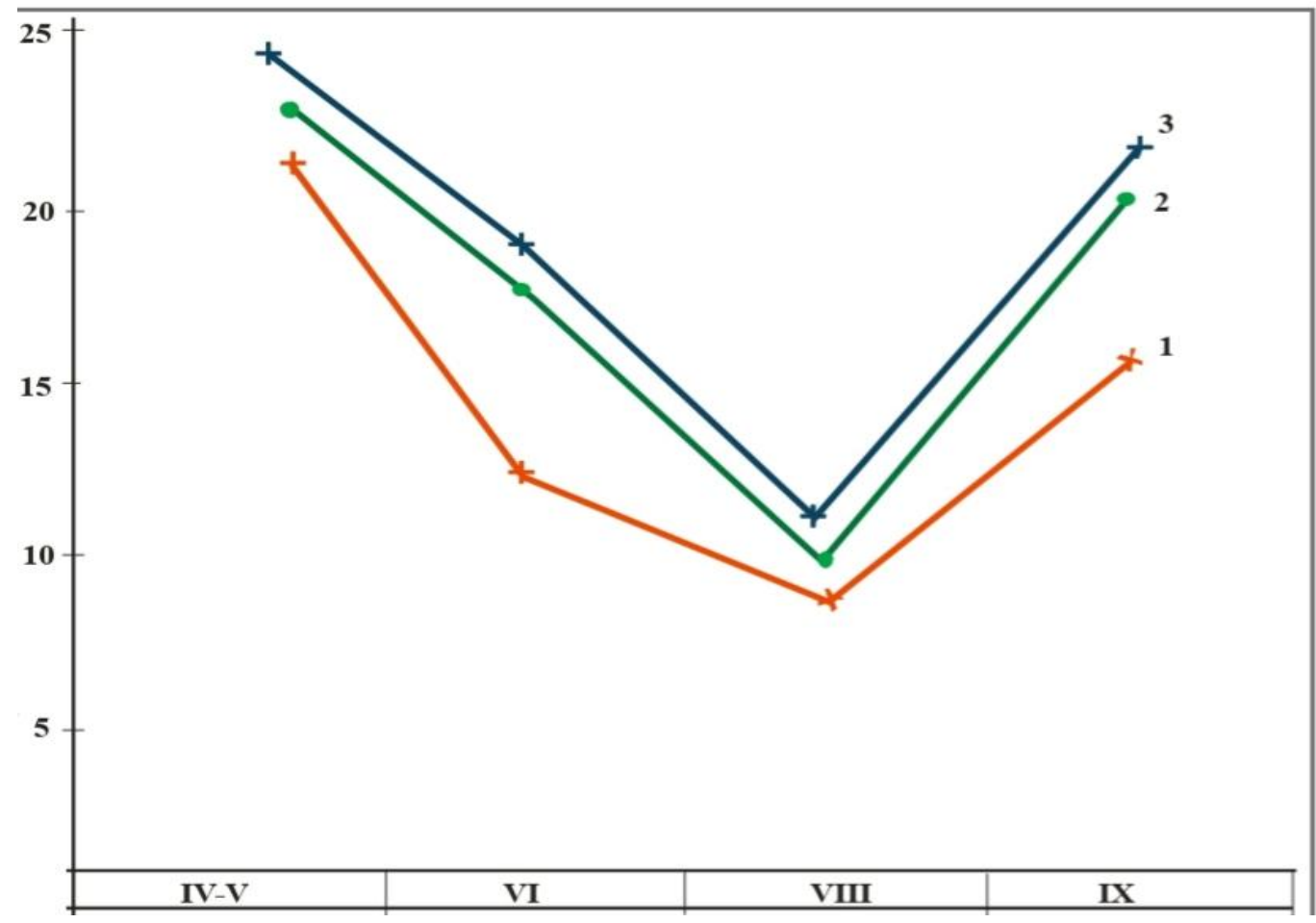

Natural cenosis 2. Cereal agrocenoses 3. Clover agrocenosis

Figure 4. Dynamics of moisture change of gray-brown (chestnut) soils in natural cenoses and agrocenoses by seasons 
The activity of the enzyme catalase was used as a diagnostic indicator to characterize the direction of biological processes in gray-brown soils. Studies have revealed some differences between natural cenoses and agrocenoses in determining the activity of catalase in soils. The cultivation of gray-brown soils stimulates enzymatic processes and increases the activity of the enzyme catalase, which is involved in oxidation reactions. The enzyme catalase breaks down hydrogen peroxide into water and molecular oxygen, which is formed as a result of the respiration of living organisms and the oxidation of organic substances in various biochemical reactions, and reflects the level soil fertility. The results of the activity of the enzyme catalase can be used, among other biological indicators, as a biodiagnostic test for gray-brown soils. The relationship between invertase activity and hydrothermal conditions, plant matter in the soil, the amount of humus and the number of microorganisms was closely related. In recent years, enzyme activity has been widely used as a key diagnostic indicator in determining the level of soil culture, genetic types and soil fertility, as well as the degree of erosion. In soils of natural cenoses and agrocenoses, an increase in microbiological activity is observed in May and June. Biological studies of graybrown soils can be used as biodiagnostic tests in the systematization and classification of gray-brown soils formed in arid ecosystems. When studying the activity of oxidizing and hydrolytic enzymes, different results were obtained on natural (wet soil) and agrocenose soils. The activity of the enzyme catalase in natural cenoses varies depending on the amount of humus and microbiota in $1.06-10.7 \mathrm{ml} \mathrm{O}_{2} / \mathrm{g}$ soil for 2 minutes and in $0.91-8.90 \mathrm{ml}$ $\mathrm{O}_{2} / \mathrm{g}$ soil for 2 minutes. 2 minutes and $4.46-13.44 \mathrm{ml} \mathrm{O}_{2} / \mathrm{g}$. Ranges from 2 minutes in the ground. Similarly, the invertase enzyme activity varied from 7.95 to $27.38 \mathrm{mg}$ glucose/g in wet soils for up to 24 hours. In agrocenoses, the invertase enzyme activity increases from 2.48 to 31.20 $\mathrm{mg}$ glucose/g in soil within 24 hours. Thus, according to the results obtained, the enzymatic activity in agronoses was higher than in natural cenoses. As a result of biological studies of gray-brown soils, invertebrates with various vital activities, common in natural cenoses, have been identified. Studying the biological characteristics of soil under crops grown in agrocenoses can protect beneficial soil biota from adverse effects when using certain chemicals to protect them from pests. Applying modern advanced agronomic and irrigation technologies to farms, it is possible to maintain stable biological activity and soil fertility. In the biological assessment of gray-brown soils of agricultural importance, it is important to use biological diagnostic indicators. According to our research, river irrigation has had a very positive effect both on agricultural crops grown in agrocenoses and on plowed soil. There was an increase in the amount of beneficial microbiota in irrigated soils and an acceleration of plant growth during the biologically active period. The comparative analysis of natural cenoses and agrocenoses taken from the territory of Goychay region shows that the lowest humidity is observed in natural cenoses. Here, the water-holding properties of the soils of the cenoses cultivated under the influence of irrigation water have increased, and the optimal conditions for the soil biota have developed in the agrocenoses.

\section{Conclusions}

The results showed that the identified microscopic fungi are involved in the formation of a rich flora, adapting to river water. Based on the results obtained, it was determined that the qualitative composition of irrigation water is suitable for obtaining optimal indicators in biotope soils and is suitable for irrigation. The results of microbiological analysis showed that the results of agroameliorative activities, such as splashing, irrigation water, crop rotation, soil quality and useful microbiota increased. Farmers can use biodiagnostic indicators for attracting raw materials to agriculture.

\section{REFERENCES}

[1] Babayev M.P., Jafarov A.M. The Book - Modern Soil Coverage of the Greater Caucasus. Azerbaijan, Baku, pp. 125-1302017.

[2] Hasanova T.A. Complexes (Ecogroups) of the invertebrates, phytomass and dynamics of microbiological population and their importance at grey-brown soils diagnostics in Azerbaijan. The article. Universal Journal of Agricultural Research, Vol. 3 No 4 (2015), 130-135. ISSN 2332-2268 DOI: 10.13189/ujar.2015.030403.

[3] Hasanova T.A. Phytotesting as a biodiagnostical parameter of grey-brown (chestnut) soils in the Karamaryam plateau. The article. Europaische Fachhochschule, ORT Publishing, (Stuttgart), Issue 11, pp. 3-6. 2014. Impact Factor (ISI) 0.356, (ICR) «European Applied Sciences» ISSN 21952183 Nationales ISSN-Zentrum für Deutschland.

[4] Hasanova T.A. General Characteristic of Microbiotes in soils of the Great Caucasus. The article. The X international scientific symposium dedicated to the 880th anniversary of Nizami Ganjavi "Science and education yesterday today tomorrow". pp. 344-348 Stockholm, Sweden. 2021.

[5] Hasanov A.B. Mathematical modeling and forecasting of floods in rivers. The book. pp.71-76 Baku, 2012

[6] Hasanova T.A. Mammadova G.I. Biological edificators of gray-brown soils. Collection of articles of the international scientific conference: Fundamental and applied research in modern world. February 17-19, 2021, pp. 124-126 Boston, USA. ISBN 978-1-73981.

[7] Mammadova G.I. The influence of organic and mineral fertilizers to the dynamics of nutrients in the soils of 
Absheron peninsula used by tomato plant // Annals of Agrarian Sciences, Georgia, 2015, Vol.13, No.2, p. 52-56.

[8] Isayeva K.K., Mammadova G.I. The biological products created on the basis of nitrogenization microorganisms and usage them in agriculture. Article. The world of science and innovation. Abstracts of I international scientific and practical conference august 19-21. UK. London 2020. p.30-33

[9] David C. Coleman, Mac A. Callaham Jr., D.A. Crossley Jr. The Book - Fundamentals of soil Ecology. Third edition. Academic press 2017. p. 317

[10] Wayne L. Teaming with microbes: The organic gardener's guide to the soil food web. Timber press. 2010. p. 120. 